\title{
Human Trafficking
}

The phenomenon of human trafficking, although subject to much debate and critique, is often portrayed as the fastest growing illegal and profitable activity in the world (Morris 2019). Globally, over 40,000,000 people are estimated to be victims of modern slavery and human trafficking across and within borders (International Labour Organisation, ILO 2017). Children are thought to account for between a quarter (ILO 2017) and a third of victims (United Nations Office Drugs and Crime, UNODC 2018). However, estimating the numbers of victims is at best good guesswork, based largely on unverified information, with no baseline data. This task is made more difficult by the definitional problems associated with trafficking and the various assumptions and claims made about both victims and perpetrators (Godziak 2016; Spencer and Broad 2012; Goodey 2008; O'Connell Davidson 2013; Weitzer 2013; 2014).

Article 4 of the Council of Europe (2005) define trafficking in human beings as:

\begin{abstract}
.... the recruitment, transportation, transfer, harbouring or receipt of persons, by means of the threat or use of force or other forms of coercion, of abduction, of fraud, of deception, of the abuse of power or of a position of vulnerability or of the giving or receiving of payments or benefits to achieve the consent of a person having control over another person, for the purpose of exploitation. Exploitation shall include, at a minimum, the exploitation of the prostitution of others or other forms of sexual exploitation, forced labour or services, slavery or practices similar to slavery, servitude or the removal of organs.
\end{abstract}

Article 4 also includes other provisions to ensure that consent of a victim is irrelevant (section 2) and that for children (any person under 18 years of age) the means (coercion, threat etc) are not required to be present (section 3). This takes into account the various methods by which a child can be manipulated into an exploitative situation.

Despite recognised international definitions, policies and practice have often developed following a political agenda, with trafficking being sensationalised, misrepresented and politicised (Koser 2000; Brennan 2005), as "anecdotal evidence 
and moral ideologies" replace any empirical data (Musto 2009:282). Sharapov (2017) believes there is often an unhealthy focus on trafficking because of the way it is framed under various discourses and perspectives - criminal justice, immigration, or human rights - as each compete for prominence. This confusion in policy, practice and conceptualisation reflects the complexities of exploitation and helps to frame how governments can problematise trafficking. Within this confused landscape Yea (2017: 2) argues that the evidence for, and understanding of, trafficking and how to respond "should never be thought of as politically neutral...truths are social, political and moral constructs".

Notwithstanding these concerns, there has been considerable effort in the UK to identify, quantify and respond to human trafficking. Official estimates about the extent of the problem have, since 2009, been based around the number of people referred to the National Referral Mechanism (NRM). The NRM is the UK policy and practice framework for identifying and referring potential victims of human trafficking and modern slavery to appropriate support. Since its introduction over 25,000 people have been referred into the NRM, although these official statistics are not considered accurate as not all victims of trafficking are identified as such, nor are all potential victims referred (Anti-Trafficking Monitoring Group, ATMG 2014).

There has also been substantial criticism of the implementation of the NRM since its inception, not least that it is overly bureaucratic and too closely aligned with immigration processes, and asylum decision-making (Annison 2013; Setter and Baker 2018). In response to criticism, the Home Office (2014) undertook a review of the referral system in order to address some of the concerns. Following an evaluation of a number of pilot areas (Home Office 2017) which demonstrated improvements in decision-making and time taken to make a decision, changes were made to the NRM in April 2019. Referrals are now made by 'first responders' (those agencies that can make a referral), via a simplified digital referral, to single 'competent authorities' (decision makers), located in the Home Office, who make the final judgement on whether a person is considered a potential victim of trafficking or not.

This paper provides an important theoretical, critical and practical contribution to the UK process for identifying unaccompanied children who have been exploited through 
trafficking. It does so at a time when policy has recently changed and the numbers identified through the official NRM referral system continue to rise. The paper has emerged from practice, policy and research experience over the last twenty years, and a growing concern at the impact of institutional and procedural factors on the social work role. It has wider resonance in terms of conceptualising both the underpinning factors and the responses to child trafficking through a broader political priority of 'neoliberal governmentality'. Much has been written about the flawed process of initial identification of child victims in an immigration/criminal justice framework, as the responses of child protection professionals are both marginalised and criticised (Setter and Baker 2018; Ishola 2011; Sereni and Baker 2018). We argue that these processes of overlooking and criticising the safeguarding experts is the result of neoliberal governmentality and the problematising of modern slavery and human trafficking as one of immigration and crime control.

While this paper focuses on the UK wide NRM policy, there are different systems in place to support victims of human trafficking in the devolved administrations. The specific responses are governed by different trafficking legislation; the Modern Slavery Act (2015) in England and Wales, the Human Trafficking and Exploitation (Scotland) Act (2015), and the Human Trafficking and Exploitation (Criminal Justice and Support for Victims) Act (Northern Ireland) 2015. An unaccompanied asylum-seeking child (UASC) is defined by the Home Office (2018a) as a person under 18 years old with no relatives or guardian in the UK who is applying for asylum in their own right. While this is the group of children and young people we are discussing, the more politically neutral terms unaccompanied children and young people are used throughout this paper. The terms child safeguarding and protection are also used interchangeably to reflect different policy and practice across the UK. Terminology is important when discussing the responses to child trafficking and is can determine how the issues are framed and responded to.

\section{Neoliberalism and human trafficking}

Neoliberalism is a contested concept, not easy to define, that generates much debate and argument in the international public sphere (Eagleton-Pierce 2016). Harvey (2007) suggests that it has become such an overriding doctrine that if effects the way we interpret and understand the world. He notes that while there are often differing 
understandings of its meaning and origin it is usually associated with a political and economic theory that proposes economic development and human well-being promoted by increased free markets and free trade. While there has been discussion of the economic costs and benefits of neoliberalism (Duménil and Lévy 2010), its negative effects on human rights and the labour market (Harvey 2007, 2010; George 2000) and the relationship between neoliberal policies and human trafficking and exploitation (Peksen et al 2017) have also been highlighted.

Social inequalities have increased dramatically since the development of a globalised, neoliberal ideology (Hill and Kumar 2009), and the resulting impact of globalisation, including international features of exploitation, have emerged to such an extent that the trafficking discourse is now conflated with the complex area of migration as people move across borders to seek improved social and economic circumstances (Howard 2017). This is despite evidence that most victims of trafficking and exploitation are identified in their country of origin (UNODC 2018). In this respect, globalisation and neoliberalism are inextricably linked and create markets that ensure vulnerability to exploitation (Kotz; Peksen et al 2017), where vulnerable people may become victims of human trafficking - the 'collateral damage' (Bauman 2011) of the social inequalities created by the drive for increased economic benefits.

In the UK discussion has also developed in the context of an increasingly hostile environment for migrants (Hek 2005), and debates around Brexit have further polarised immigration discourse. These discussion have been described as a crisis of both migration and neoliberalism (Mulvey and Davidson 2018). This resonates with wider concerns that neoliberal policies generate anti-migrant attitudes (Akira and Yoshikuni 2019). Such concerns often result in immigration policies that have particular impact on social work and child protection practice, as immigration law is often prioritised (Ramsay 2020; Shall 2018).

While neoliberalism has been identified as a driver of the exploitation of people through the continual impact of globalised profit-making, it has also been identified as a crucial approach to determining how states identify and work with victims. A key aspect of corporate governance and neoliberal practice involves expert partnerships coming together to address pressing social issues through centralisation of policy and agreed 
aims and objectives. Central government defines priorities, creates and maintains the framework, but is not directly responsible for delivering support, instead placing the responsibility for co-ordinating responses outside its explicit remit (Ling 2000; Pratt 1989; Harvey 2007). Under neoliberal orthodoxy, as state provision for many areas of social policy declines, delivery of services is provided by NGOs and the third sector (Hyslop 2018; Webb 2006; Culpitt 1998; Spolander et al 2014). Gadd and Broad (2018) identify that in the UK there are over 70 independent NGO's working in the area of human trafficking, and many of these have developed 'expertise' to provide training and awareness-raising to a range of professionals (Van Dyke 2017). Garret's (2009: 9) characterisation of neoliberalism as helping to create a hegemonic 'coalition of the willing' is reflected in the numbers of agencies working in the 'rescue industry' (Connelly 2015).

"Procedures, performance indicators and eligibility criteria" (Rogowski 2011:162) are the hallmark of neoliberal governance and in relation to human trafficking the NRM is the most visible example of this. Through the NRM the government retains control and access to services and ensures that while identification of trafficking victims is determined by the 'gatekeepers' (single competent authorities), these decision makers for eligibility of welfare services are not responsible for the delivery of support to victims. The NRM itself (procedures), the timeframes for submission and responses (performance measurements) and the indicators of (child) trafficking (eligibility to be identified as a victim) encapsulate neoliberal practice, and represent an attempt to reduce the complexities of human trafficking to a more easily administered bureaucratic process. For children, delivery of services has been devolved to a local authority level, and for Scotland and Northern Ireland this 'fragmentation of responsibility' (Raine and Wilson 1997) is even more stark as the identification of victims remains centralised within the Home Office, while delivery of support services is governed by devolved legislation (both for trafficking and child welfare responsibilities).

Within responses to trafficking in the UK the complex relationships between movement, migration, exploited people and those who facilitate movement and exploitation (Spencer and Broad 2012) have been reduced to simple and realisable policy goals that hide the structural and causal factors of exploitation and trafficking 
(Arocha 2013; Andrijasevic and Mai 2016). As Davies (2010) suggests, in time of uncertainty and unknown risks the neoliberal approach ignores complexities, reduces ambiguity and introduces performance evaluation to manage perceived problem issues. This reductionism, or severing from social reality (Bourdieu 1998), is a hallmark of classic neoliberal social policy - in trafficking multifaceted issues are now reduced to simple categories of individuals (good and bad, victims and perpetrators) and (expert) responses with little reference to broader socio-economic conditions.

The government, through the NRM and related strategy and guidance, has framed the problem largely as one of immigration and criminal justice; has directed the policy and practice (Broad and Turnbill 2018) and defined who is a victim and 'deserves' support, while at the same time outsourcing the delivery of services. Garrett (2019) identifies this contradictory role of government as being one of the paradoxes of neoliberalism where the rhetoric often suggests less government involvement (at the point of support and service delivery with trafficking), while in practice there is often more involvement at the policing and surveillance level (see also Garland 2012).

\section{Child Trafficking}

Responses to the trafficking and exploitation of children is also an area that has been characterised by neoliberal influence. As indicated above, children account for a third to half of all identified trafficking victims identified globally. In the UK the numbers of children referred to the NRM has risen annually since 2009 and, over the last two years, the numbers have increased substantially from 2,118 in 2017 to 3,071 in 2018 (NCA 2019). Much of this increase relates to referrals of UK national children, largely the result of identifying child sexual exploitation, 'county lines' and child criminal exploitation concerns (Home Office 2018b). Notwithstanding the official referral statistics, and with little doubt that children are moved to the UK and exploited, there remains substantial debate regarding the extent of child trafficking into the UK (Westwood 2016). While this paper focuses specifically on unaccompanied non-UK national children, many of the concerns about the response to victims of trafficking also relate to other groups of children and young people.

Child trafficking is recognised internationally as constituting child abuse and in recognition of the particular vulnerabilities of children, including issues of consent and 
agency (see Gozdziak 2016), state parties are obliged to ensure that there are specific provisions in place for the assessment and support of children (see EU Parliament 2011). Yet despite calls not to treat child trafficking as merely a sub-category of human trafficking (ECPAT 2010; Wallace and Wylie 2011), the response, also via the NRM, locates responsibility for the identification of abused and exploited children who arrive in the country with border control (and initially criminal justice) agencies (ATMG 2010; Sereni and Baker 2018). This ignores the acknowledgment made prior to the introduction of the NRM that identification and support was within the remit of local authority social work services and partner agencies (Rigby and Ishola 2016). In effect, the identification decision-making process marginalises social workers, and other children's services professionals, and their involvement remains a largely paper based exercise (Ishola 2011). The NRM process for children involves completion of a child specific NRM referral form by the first responder, which is then sent to the single competent authority to make a decision; this may, or may not, involve further discussion with children's services, and almost certainly does not involve meeting with the child or young person. Unlike adults, children do not have to consent to a referral.

Since its introduction the relevance and appropriateness of the NRM for child victims has consistently been questioned (ATMG 2010; London SCB 2011). In effect, what would in any other manifestation be a social work task - the identification and support of abused and exploited children - rests on the decisions of newly created (in 2009) partnerships for identifying suspected trafficking victims. As Harvey et al (2015) highlight, the single competent authorities are considered the leads and experts on child trafficking. This label of 'expertise' has probably emerged because the competent authorities were given the remit for identification when the NRM was first developed.

The focus on specific routes to identification by 'trafficking experts', serves to maintain a focus on unaccompanied children's differences as migrants, rather than their potential needs as children. This helps to constitute a process of 'othering' (Masocha 2015; Staerklé 2013) in both policy and practice as "stereotypical trafficking representations" (Andrijasevic, and Mai 2016: 3) assume a collective identity for trafficked children and contribute to a focus on movement (migration) as the locus of exploitation and abuse for children. These assumptions often mean that the movement of children automatically indicates 'risk' and possible exploitation, while ignoring the 
agency of children in decisions to move, and overlooks the reality that trafficking is likely to be only one type of abuse along a continuum of exploitation or risk (Howard 2017; Sharapov 2017; Van Dyke 2017).

\section{Neoliberal policy and practice criticism}

Practice and policy responses to the exploitation of unaccompanied children have striking similarities to neoliberal orthodoxies identified elsewhere in relation to child safeguarding and protection. Neoliberalism has been linked to increased bureaucracy, managerial techniques and close monitoring in the welfare state, impacting on some of the most vulnerable people (Stark 2017; Knox Haly 2010; Parton 2014; Rogowski 2015; Spolander et al 2014; Garrett 2009; 2019). It has resulted in increased criticism of, and challenges to, welfare provision, with blame for any failures attributed to professions and individuals, rather than systemic shortcomings (Stark 2017; Aronson and Hemingway 2011; Jonsson 2019).

With public service cuts and the austerity agenda viewed as part of neoliberal policy there is evidence of particular negative impacts on children resulting from the reduction of resources to children and families social work (Singh and Cowden 2015; Rogowski 2015). This has been accompanied by an increase in managerial systems for child protection (Knox-Haly 2010) and, as public sector social workers are continually criticised for not being good enough (Gwilym 2018), there is also increased provision of services by the third sector in child safeguarding (Rogowski 2018). Additionally, social work practitioners have become more embroiled in administrative risk assessments in order to ration resources, thus deflecting attention from the broader structural factors that underpin the circumstances they are required to address (Rogowski 2018).

While there have been criticisms of the NRM as a system for identification of children there has been corresponding, and specific, criticism of the failure of social work and children's services to identify and respond appropriately (Hynes 2010; Pearce 2011; Howard 2017; ECPAT 2009; ATMG 2014; Harvey et al 2015; West 2016), not least because child trafficking is viewed as a particularly complex process (Gozdziak and MacDonnell 2007; Harvey et al 2015). Social workers have also been criticised for mirroring the role of the Home Office and immigration officials in relation to children on 
the move (Humphries 2004). Perhaps, as Rogowski (2018:18) has also argued for other child protection priorities, it is a position they have been forced into because of the neoliberal world of austerity and scarce resources where their role is reduced to "merely intrusively asking questions, gathering information and.....inspecting..... lifestyles."

Reliance on the technical application of assessment instruments (NRM form and child trafficking matrix which provides the 'indicators' of trafficking) may also erode the wider social work task and role of raising a critical awareness of abuse and exploitation (Hyslop 2016). For children exploited through trafficking this involves their categorisation as 'trafficked children' rather than as children with a range of risks and needs, one of which may be exploitation and abuse through trafficking. Cree et al (2014) also suggest that this focus on trafficking (however it is variously defined), diverts attention away from broader child welfare, support and protection issues, or social justice and human rights abuses.

In reality, the governmentality of responses to the trafficking of unaccompanied children also appears to be based upon a neoliberal approach. While such a neoliberal analysis has been discussed elsewhere for both child exploitation and trafficking, the link with similar developments within child welfare and safeguarding provides an opportunity here to consider a (not so) radical change that goes far beyond recent reforms of the NRM. A new practice model would ensure that children are not 'othered' by having their identification as victims of child abuse determined by a different agency and process than all other victims of child abuse across the UK.

\section{What should it look like?}

While we have argued that decisions to bypass the existing child safeguarding and protection structures in the identification of child victims of trafficking can be located in a wider neoliberal agenda, we are also conscious that if not the present NRM system - what? Solutions to this question lie not only in policy and practice responses but also in the broader understanding of the extent of the issues, the contributory factors and, notwithstanding some of the concerns about the concept (see McLaughlin 2017), a child first, migrant second approach (Crawley 2006). 
The UK has well-established child protection and safeguarding processes which, while not always working well, are recognised as a relative success story (Rogowski 2014; Pritchard and Williams 2010). While 'child protection' has often focused on particular issues or on specific groups of children (FRA 2019), recent practice and policy developments in the UK has broadened understanding and definitions of child abuse to include abuse outside the 'family' home (Malloch and Rigby 2020). Concerns around child trafficking broaden definitions and understanding of exploitation and abuse, with the additional challenges for policy makers and child protection practitioners (Lonne et al 2008), but continuing with the identification of exploited children outside the existing child protection system is difficult to justify and arguably does not adequately provide an integrated child protection system which places the child at the centre and ensures that all essential services work together to protect the child (FRA 2019; UNICEF 2015). It is this principle of an integrated system, coupled with the wider internationally recognised remit of social workers to adopt a rights based, social justice approach, that informs a proposed practice model that places both social workers and children at the centre of the identification and decision making process.

In England and Wales, it has been suggested that the identification of trafficked children would better fit with the child protection system if children were referred simultaneously to multi-agency safeguarding hubs for a determination of their trafficking status, and the local authority child protection systems for care and protection issues (ATMG 2014). The ATMG argued this would ensure their wider risk and needs would also be addressed, even if there was a negative decision from the competent authority, although Murie and Owens (2016) suggest this may not always happen as the child protection decision can be overruled. ECAPT UK (2017) and Sereni and Baker (2018) developed the ATMG model further, suggesting that any reforms should ensure that government departments with responsibility for children lead on the issue.

In Scotland there have been calls for the elimination of a separate competent authority identification system for children exploited through trafficking and instead, to refer all concerns via the existing child protection system. A multi-agency case conference could then make an initial determination and identification of trafficking as a concern, 
and refer to the NRM (Rigby and Ishola 2016). In effect, the identification, assessment and follow on support and monitoring would be managed in one child protection system, albeit mitigated through a referral to the existing NRM and competent authorities.

Across the UK, UNICEF (2015) identified that the immigration and child protection systems ran on parallel lines in relation to unaccompanied children, with workers waiting for trafficking decisions before assessing and addressing protection needs. UNICEF called on the UK government to ensure that child trafficking was addressed as a child protection issue and that the NRM worked more efficiently to recognise child victims, with the best interests of the child being the primary concern.

These suggestions do not go far enough. We now argue that for both a practice and rights based perspective in the best interests of children, the identification, assessment and support of children exploited through trafficking rests wholly within the existing child safeguarding and protection framework, managed by social workers, with the support of partner agencies. The Home Office should have no responsibility for deciding if a child is a victim of exploitation. The wholesale shifting of responsibility to those child safeguarding and protection and agencies whose primary role is child welfare would address the issue of fragmentation of response and assuage concerns about new expert partnerships solely for trafficking that exist outside the child protection system. Such an approach would provide for a more child focussed 'durable solution' that addresses all protection needs and takes into account the child's views (UNICEF 2015).

The recent changes to the system for identifying all victims of trafficking, which also introduces a multi-agency backstop, do not address the fundamental concern that children exploited through trafficking are identified through a paper (digital) based system, that sits outside traditional child safeguarding frameworks. These recent changes merely maintain the neoliberal governance, where central government hold onto the strategy, policy and decision making, while devolving delivery and support to localities. 
In the context of the continuing challenges faced by the NRM pilots (Home Office 2017) our proposed model would facilitate child welfare decision-making and provision of services being managed within one child protection system. One of the challenges faced by the new decision makers in the pilot areas related to gathering information, and waiting for police and immigration interviews to be completed before trafficking decisions were made (Home Office 2017). If the decision-making was undertaken by a multi-agency child protection / safeguarding conference, in line with various UK child protection guidance, joint social work and police interviews would be part of this process and additional interviews and processes would not be required to determine if a child has been trafficked, or requires additional support to address risk and needs. It would all be part of the same process.

The Home Office (2017) also identified the separation of case-working and decisionmaking as an issue. This is mitigated in our child protection case conference model as social workers, and other partners (most notably independent child trafficking guardians, see Crawley and Kohli 2013; Kohli et al 2015), already working with the child will be involved directly at the meetings making the trafficking determination. Decision-making at child protection case conferences would also allow for the possibility for children and young people to be present, if safe and appropriate, centring the voice of the child in the system and further meeting international good practice regarding an 'integrated child protection system' (FRA 2019) for all children. Resourcing as an issue (Home Office 2017) is also addressed as case conferences meet anyway whenever there are child protection concerns.

In terms of obligations to international conventions requiring state parties to identify victims of trafficking, it is the identification and appropriate support that is important, not a specific, rigid, National Referral Mechanism. Indeed the original OSCE (2014) model for a NRM envisaged a cooperative framework, involving state actors and civil society to identify victims. More recently, the European Commission (2018) defined NRM as a 'mechanism aimed at identifying, protecting and assisting victims of trafficking in human beings, through referral, and involving relevant public authorities and civil society'. The mechanism has existed in the UK for many years in the form of a child protection case conference. 
For the social work profession, the contributory factors and broader structural understanding required as part of an assessment process (Rigby and Whyte 2015), will also engage the wider priorities of social workers in relation to human rights and social justice (IFSW 2014; Singh 2015). Rogowski (2014) has argued that social workers need to take a more critical stance in relation to their work with victims of abuse and exploitation, locating victimisation in the broader socio-economic conditions that lead to and permit exploitation. This is perhaps even more crucial in the context of the lives of separated children. These circumstances can lead to a range of quite exceptional needs, which require "meaningful assessments...facilitated by professionals who are appropriately skilled, committed to basic social work principles, and able to draw on knowledge that will assist them and the children and young people" (Mitchell 2007: 59). Comprehensive assessments, involving children, and encompassing all aspects of their lives and experiences, incorporates a rights based approach and ensures Rogowski's critical stance.

Such an approach is not without potential problems given the preceding discussion regarding criticism of local authority responses. It would require increased training for child protection professionals to overcome the concerns about lack of awareness of trafficking and its indicators (West 2017; ATMG 2014; Harvey et al 2015) and to ensure unaccompanied children and young people are not lost amongst all the other complex child protection cases (Gozdziak and MacDonnell 2007). Additionally, clearer links between agencies present at cases conferences and other aspects of the justice and immigration systems would need to be established, although there is precedence for Home Office officials attending child protection case conference (see Murie and Owens 2016). There would also need to be consideration given to accessing criminal injuries compensation following a decision by a child protection case conference, in the absence of any criminal action against the traffickers. This liaison between these different parts of the system could retain the name 'NRM' if required.

\section{Conclusion}

There has been much written about problems with the identification of children who have been exploited through trafficking; and neoliberal influences on trafficking and children and families social work practice. However, this is the first time a critique of the response to trafficking for unaccompanied children in the UK has looked more 
broadly at fundamental conceptual and practice issues in the context of a neoliberal orthodoxy. Responses to unaccompanied asylum seeking children in the UK who have been exploited through trafficking have not occurred by accident, but as part of a continuing neoliberal governance that has impacted on other aspects of the UK's child protection systems and understanding of human trafficking globally. While child trafficking widens the definition of child abuse, and brings additional challenges, it is essentially a child safeguarding issue. Social workers and children's services professionals should be tasked both with its identification and support.

A neoliberal approach in children and families social work has ensured that the responses to child abuse are no longer a medico-social problem with social workers as lead professionals, but a criminal justice concern with a shift towards identification, information gathering and conviction, rather than direct work with, and support, for children (Rogowski 2018). This is reflected in the response to child trafficking where social workers are not the lead professionals. The NRM and the competent authorities became the new partnerships, relying on the completion of referral forms to gather the information and assist with decision-making, without any direct work with children. It was perhaps inevitable that criticism of social workers and other child protection professionals would follow when those professionals, whose primary role is safeguarding vulnerable children, are marginalised in the identification and decision making processes. Arguably, the lack of training and awareness for child protection professionals was also a consequence of the decision to locate trafficking expertise and the job of identification with 'expert' competent authorities (Harvey et al 2015). It is a paradox of practice in this area of child safeguarding that the identification of children at risk, or abused, through trafficking has been taken away from those agencies who work directly with children and whose primary expertise is child safeguarding and protection, while at the same time, these agencies are criticised for not identifying children who have been victims of trafficking. Questioning the competence of social work and other children's services to identify and support all children in need has maintained a policy and practice distinction between unaccompanied children who have been trafficked and UK born children experiencing other types of exploitation. 
While not ignoring or diminishing the complex arguments that surround the issue of exploitation and trafficking, nor the criticism that has been levelled at children's services responses, it makes no sense to further alienate and 'other' migrant children. The present NRM process involves continuing to subject them to an overly bureaucratic, method of questioning and identification that lies primarily within a border control system. The Home Office is under statutory obligation to safeguard and promote the welfare of children in discharging its duties under Section 55 of the Borders, Citizenship and Immigration Act 2009, and considerable efforts have been made to comply with this requirement. However, there can be no doubt those child protection authorities whose primary duty is the protection of children, and who have the experience, training and expertise required to identify and provide care to exploited children, are in a better position to ensure that identification and subsequent interventions are child centred and in a child's best interest. As such, and as a first move to de-politicise the responses to child trafficking, the present decision-making process located in the Home Office, should be transferred fully to the 'experts' in child safeguarding and protection.

However, it is also recognised that responses to asylum seekers is not entirely unproblematic among the social work profession (Masocha 2015). Whether a new practice model mitigates against the 'othering' of child migrants, and criticism of social workers, remains to be seen, but it may help to develop a 'child first, migrant second' thinking and response in the UK (Crawley 2006). Ultimately, "child trafficking needs to be recognised as a highly complex area of child protection" (Ishola 2011: 99) and the marginalisation of children's services professionals needs to end. Any changes will require careful monitoring going forward - the emerging independent child trafficking guardians will be key partners for local authority social workers over the next few years - and training and awareness raising amongst child safeguarding professionals would require attention to ensure victims of trafficking do not fall through the net.

As the numbers of children from the UK and abroad identified as victims of trafficking continues to rise now is the time to ensure that child safeguarding professionals take centre stage in their identification and support, so that all children who are exploited and abused receive the same response. Conceptually, such an approach would ensure that concerns about migration, border security and associated risks would be 
a secondary concern to the immediate needs and safety of a child. If the route into a system of support and protection remains in a centralised, immigration led identification route, unaccompanied children will continue to be labelled as different and subsequent responses mitigated through disparate systems.

The Authors declare that there is no conflict of interest

Thank you to the reviewers who provided helpful comments on the text

Akari, I. and Yoshikuni, O. (2019) Neoliberalism and Negative Attitudes toward Immigrants RIETI Discussion Paper Series 19 -E-085

https://www.rieti.go.jp/jp/publications/dp/19e085.pdf [Accessed 18 June 2020]

Andrijasevic, R. and Mai, N. (2016) Editorial: Trafficking (in) Representations: Understanding the recurring appeal of victimhood and slavery in neoliberal times in Anti Trafficking Review 7, 1-11

Annison, R. (2013) In the Dock: Examining the U.K.'s Criminal Justice Response to Trafficking Anti-slavery International

https://www.antislavery.org/wp-content/uploads/2017/01/in the dock final.pdf

[Accessed 27 October 2019]

ATMG - Anti-Trafficking Monitoring Group (2010) Wrong Kind of Victim? One Year On: An Analysis of UK Measures to Protect Trafficked Persons London, AntiTrafficking Monitoring Group

https://www.ecpat.org.uk/wrong-kind-of-victim-one-year-on-an-analysis-of-ukmeasures-to-protect-trafficked-persons [Accessed 24 September 2019]

ATMG - Anti-Trafficking Monitoring Group (2014) Proposal for a Revised National Referral Mechanism (NRM) for Children London, Anti-Trafficking Monitoring Group https://www.ecpat.org.uk/Handlers/Download.ashx?IDMF=9c439adf-97ef-45f8-ad4fc73752f2676d [Accessed 27 October 2019]

Arocha, L. (2013) Intersections in trafficking and child sexual exploitation policy in Melrose, M. and Pearce, J. (Eds) Critical Perspectives on Child Exploitation and Related Trafficking Basingstoke, Palgrave Macmillan

Aronson, J. and Hemingway, D. (2011) 'Competence' in neoliberal times: Defining the future of social work Canadian Social Work Review 28, 2, 281-285

Bauman, Z. (2011) Collateral Damage: Social Inequalities in a Global Age Cambridge Polity Press

Bourdieu, P. (1998) 'The essence of neoliberalism' in Le Monde Diplomatique http://mondediplo.com/1998/12/08bourdieu [Accessed 1 October 2019] 
Brennan, D. (2005) Methodological challenges in research with trafficked persons: lessons from the field' in Laczko. F, and Gozdziak, E. (eds) Data and Research on Human Trafficking: A Global Survey International Organization Migration https://publications.iom.int/system/files/pdf/global survey.pdf [Accessed 1 October 2019]

Broad, R. and Turnbill, N. (2018) From human trafficking to modern slavery: the development of anti-trafficking policy in the UK European Journal of Criminal Policy Research 25, 119-133

Connelly, L. (2015) 'The rescue industry:' The blurred line between help and hindrance' Graduate Journal of Social Science 11(2), 145-160

Council of Europe (2005) Council of Europe Convention on Action against Trafficking in Human Beings https://rm.coe.int/168008371d [Accessed 27 October 2019]

Crawley, H. (2006) Child First, Migrant Second: Ensuring that Every Child Matters London, Immigration Law Practitioners' Association Policy Paper

Crawley, H. and Kohli, R.K.S. (2013) She Endures With Me: An evaluation of the Scottish Guardianship Service Pilot, Swansea University, University of Bedfordshire http://www.scottishrefugeecouncil.org.uk/wp-content/uploads/2019/10/She-endureswith-me-Final-evaluation-of-the-Scottish-Guardianship-Service-Pilot-PDF.pdf [Accessed 11 November 2019]

Cree, VE., Clapton, G., Smith, M. (2014). The Presentation of Child Trafficking in the UK: an old and new moral panic. British Journal of Social Work, 44(2), 418-433

Culpitt, I. (1998) Social Policy and Risk London, Sage

Davies, W. (2010) The Politics of Externalities: Neo-liberalism, Rising Powers and Property Rights ESRC Rising Power Programme 2010-2011

https://www.compas.ox.ac.uk/wp-content/uploads/WP-2010-OS

Davies Social Externalities Neo-Liberalism.pdf [Accessed 1 October 2019]

Duménil, G. and Lévy, D. (2010) The Crisis of Neoliberalism Harvard University Press

Eagleton-Pierce, M. (2016) Neoliberalism: The Key Concepts London, Routledge

ECPAT (2010) Child Trafficking in the UK: A Snapshot London, End Child Prostitution and Trafficking UK https://www.ecpat.org.uk/child-trafficking-a-snapshot [Accessed 20 October 2019]

ECPAT (2017) Time to Transform: Results of a survey of frontline professionals on the National Referral Mechanism for child victims of trafficking and modern slavery London, ECPAT UK https://www.ecpat.org.uk/Handlers/Download.ashx?IDMF=cdbe8012-7267-41eead51-1569beddb095 [Accessed 20 October 2019]

European Commission (2018) National Referral Mechanism 
https://ec.europa.eu/home-affairs/what-we-

o/networks/european migration network/glossary search/national-referralmechanism en [Accessed 29 October 2019]

European Union Parliament (2011) Directive 2011/36/EU of the European

Parliament and of the Council of 5 April 2011 on preventing and combating trafficking in human beings and protecting its victims

https://eur-lex.europa.eu/legal-content/en/TXT/?uri=CELEX\%3A32011L0036

[Accessed 11 November 2019]

FRA - European Union Agency for Fundamental Rights (2019) Children Deprived of Parental Care Found in an EU Member State Other Than Their Own Luxembourg, FRA

Gadd, D. and Broad, R. (2018) Troubling recognitions in British responses to modern slavery British Journal of Criminology 58, 1440-1461

Garland, D. (2012) The Culture of Control: Crime and Social Order in Contemporary Society Oxford University Press

Garrett, P. (2009) Transforming Children's Services: Social Work, Neoliberalism and the 'Modern' World Maidenhead, McGraw-Hill Education

Garrett, P. (2019) What are we talking about when we talk about 'neoliberalism'? European Journal of Social Work 22, (2), 188-200

George, S. (2000) 'Neoliberalism', in Bircham, E. (ed) Anti-Capitalism: a Guide to the Movement London, Bookmarks

Goodey, J. (2008) Human trafficking: Sketchy data and policy responses Criminology and Criminal Justice 8(4) 421-442

Gozdziak, E.M. (2016) Forced victims or willing migrants? Contesting assumptions about child trafficking in Seeberg, ML. and Gozdziak, EM. (eds) Contested Childhoods: Growing up in Migrancy IMISCOE Research Series

Gozdziak, E.M., \& MacDonnell, M. (2007) Closing the gaps: The need to improve identification and services to child victims of trafficking Human Organization, 66, 171184

Gwilym, H. (2018) Social work, neoliberalism and authoritarianism: an analysis of the policy document 'Regulating social workers' Critical and Radical Social Work 6(3) 40713

Harvey, J. (2007) Neoliberalism as creative destruction The Annals of the American Academy of Political and Social Science 1, 21-44

Harvey, D. (2010) A Brief History of Neoliberalism Oxford, Oxford University Press 
Harvey, JH., Hornsby, RA., Sattar, Z. (2015) Disjointed service: An English case study of multiagency provision in tackling child trafficking British Journal of Criminology 55, $494-513$

Hek, R. (2005) The Experiences and Needs of Refugee and Asylum Seeking Children in the UK: A Literature Review University of Birmingham

www.dera.ioe.ac.uk/53981/1/RR635.pdf [Accessed 5 June 2020]

Hill, D. and Kumar, R. (2009) Neoliberalism and its impacts in Hill, D. and Kumar, R. (eds) Global Neoliberalism and Education and Its Consequences London, Routledge

Home Office (2014) Review of the National Referral Mechanism for Victims of Human Trafficking London, Home Office

Home Office (2017) An Evaluation of the National Referral Mechanism Pilot London, Home Office

Home Office (2018a) How many people do we grant asylum or protection to? London, Home Office

Home Office (2018b) Criminal Exploitation of Children and Vulnerable adults: County Lines Guidance London, Home Office

Howard, MN. (2017) Child Trafficking, Youth Labour Mobility and the Politics of Protection London, Palgrave Macmillan

Humphries, B. (2004). An Unacceptable role for Social Work: Implementing immigration policy British Journal of Social Work, 34(1), 93-107

Hynes, P. (2010) Global points of 'vulnerability': understanding processes of the trafficking of children and young people into, within and out of the UK The International Journal of Human Rights 14(6), 952-970

Hynes, P. (2015) No 'magic bullets': Children, young people, trafficking and child protection in the UK International Migration 53(4), 62-76

Hyslop, I. (2018) Neoliberalism and social work identify European Journal of Social Work 21(1), 20-31

IFSW - International Federation of Social Workers (2014) Global definition of social work https://www.ifsw.org/what-is-social-work/global-definition-of-social-work/ [Accessed 29 October 2019]

International Labour Organization (2017) Global Estimates of Modern Slavery International Labour Organization / Walk Free Foundation Geneva

https://www.ilo.org/wcmsp5/groups/public/---dgreports/--dcomm/documents/publication/wcms 575479.pdf [Accessed 12 September 2019]

Ishola, P. (2011) Assessment, identification and care for suspected victims of child trafficking: A children social care approach in Chandran, P. (ed) Human Trafficking 
Handbook London, LexisNexis

Jonsson, JH. (2019) Servants of a 'sinking titanic' or actors of change? Contested identities of social workers in Sweden European Journal of Social Work 22, (2) 212224

Knox Haly, M. (2010) Neoliberalism and Child Protection: A Deadly Mix Labour History $98,121-141$

Kohli, RKS., Patricia Hynes, P., Connolly, H., Thurnham, A., David Westlake, D., D'Arcy, K. (2015) Evaluation of Independent Child Trafficking Advocates Trial: Final Report London, Home Office http://www.anti-trafficking.lt/docs/icta-horr86.pdf [Accessed 12 November 2019]

Kotz, DM. (2002) Globalization and Neoliberalism, Rethinking Marxism, 14:2, 64-79, DOI: $10.1080 / 089356902101242189$

Koser, K. (2000) 'Asylum policies, trafficking and vulnerability' International Migration 38(3), 91-109, Special Issue

Ling T (2000) Unpacking partnership: the case of health care in Clarke, J. Gewirtz, S. and McLaughlin, E. (eds) New Managerialism New Welfare London, Sage

London SCB (2011) Local Authority Pilots of the London Safeguarding Trafficked Children Guidance and Toolkit London Safeguarding Children Board Lonne, B., Parton, N., Thomson, J., Harries, M., (2008) Reforming Child Protection London, Routledge

Malloch, M. and Rigby, P. (2020) The complexities of 'home': young people 'on the move' and state responses Howard Journal of Crime and Justice 59(2), 158-173

Masocha, S. (2015) Construction of the 'other' in social workers discourses of asylum seekers Journal of Social Work 15(6) 569-585

McLaughlin, C. (2017) They don't look like children': child asylum-seekers, the Dubs amendment and the politics of childhood Journal of Ethnic and Migration Studies, 44(11), 1757-1773.

Mitchell, F. (2007) Assessment practice with unaccompanied children: exploring exceptions to the problem, in Kohli, R. and Mitchell, F. (eds) Working with Unaccompanied Asylum Seeking Children: Issues for Policy and Practice Basingstoke, Palgrave Macmillan

Morris, JM. (2019) Human Trafficking is a Global Epidemic. And we can help fight it https://edition.cnn.com/2019/01/14/perspectives/human-trafficking-fight/index.html [accessed 9 October 2019] 
Mulvey, G. and Davidson, N. (2018) Between the crises: Migration politics and the three periods of neoliberalism Capital and Class 43(2) 271-292

Murie, S. and Owens, L. (2016) Does it happen here? In Malloch, M. and Rigby, P. (2016) Human Trafficking: The Complexities of Exploitation Edinburgh University Press

Musto, JL. (2009) What's in a name: conflations and contradictions in contemporary US discourse of human trafficking Women's Studies International Forum 32, 281-287

National Crime Agency (2019) National Referral Mechanism Statistics End of Year Summary 2018 https://nationalcrimeagency.gov.uk/who-we-are/publications/282national-referral-mechanism-statistics-end-of-year-summary-2018/file [Accessed 20 October 2019]

O'Connell Davidson, J. (2013) 'Telling tales: Child migration and trafficking' Child Abuse and Neglect 37, 1069-1079

OSCE (2014) National Referral Mechanisms: Joining Efforts to Protect the Rights of Trafficked Persons A Practical Handbook Warsaw, OSCE https://www.osce.org/odihr/13967?download=true [Accessed 20 October 2019]

Parton, N. (2014). The Politics of Child Protection: Contemporary Developments and Future Direction. Basingstoke: Palgrave Macmillan

Pearce, J. (2011) Working with trafficked children and young people: Complexities in Practice British Journal of Social Work 41, 1424-1441

Peksen, D., Blanton, SL., Blanton, RG. (2017) Neoliberal policies and human trafficking for labor: Free markets, unfree workers? Political Research Quarterly 70(3), 673-686

Pratt, J. (1989) Corporatism: the third model of juvenile justice The British Journal of Criminology 29 (3) 236-254

Pritchard, C. and Williams, R. (2010) Comparing possible child abuse related deaths in England and Wales with the major developed countries 1974-2006: Signs of progress? British Journal of Social Work 40, 1700-1718

Raine, JW. and Wilson, MJ. (1997) 'Beyond managerialism in criminal justice' Howard Journal 36(1), 80-95

Ramsay, A (2020) Social work with unaccompanied asylum seeking children in Scotland IRISS Insight 51 https://www.iriss.org.uk/resources/insights/social-workunaccompanied-asylum-seeking-children-scotland [Accessed 18 June 2020]

Rigby, P. and Ishola, P. (2016) 'Child Protection for Child Trafficking Victims' in Malloch M \& Rigby P (eds) Exploitation: The Complexities of Human Trafficking, Edinburgh University Press 
Rigby, P. and Whyte, B. (2015) 'The importance of children's narrative within a multicentred, dynamic ecological framework for child trafficking assessment and planning' British Journal of Social Work 45(1), 34-51

Rogowski, S. (2011) Managers, managerialism and social work with children and families: the deformation of a profession? Practice: Social Work in Action 23,(3), 157167

Rogowski, S. (2012) Social work with children and families: Challenges and possibilities in the neo-liberal world British Journal of Social Work 42, 921-940

Rogowski, S. (2014) Critical social work in child protection / safeguarding: Challenges and (fewer) opportunities Critical and Radical Social Work 2(1), 43-58

Rogowski, S. (2015) Margaret Thatcher's legacy for social work with children and families: critical possibilities? Critical and Radical Social Work 3(1), 53-65

Rogowski, S. (2018) Neoliberalism and social work with children and families in the UK: On-going challenges and critical possibilities Aotearoa New Zealand Social Work 30(3), $72-83$

Rose, N., O’Malley, P., Valverde, M. (2006) Governmentality Annual Review Law Society 2, 83-104

Sereni, A. and Baker, C. (2018) Before the Harm is Done: Examining the UK's Response to the Prevention of Human Trafficking London, Anti-Trafficking Monitoring Group

Setter, C. and Baker, C. (2018) Child Trafficking in the UK 2018: A Snapshot London, ECPAT UK

Shall, S (2018) Immigration law is often prioritised at the expense of the child's wellbeing' Community Care October 12

https://www.communitycare.co.uk/2018/10/12/immigration-law-often-prioritised-

expense-childs-wellbeing/ [Accessed 18 June 2020]

Sharapov, K. (2017) 'Traffickers and their victims' anti-trafficking policy in the United Kingdom Critical Sociology 43(1) 91-111

Singh, G. and Cowden, S. (2015) The intensification of neoliberalism and the commodification of human need - a social work perspective Critical and Radical Social Work 3(3), 375-387

Smith, M., Clapton, G., Cree, V. (2016) Moral panics and beyond in Cree, V., Clapton, G., Smith, M. (eds) Revisiting Moral Panics Bristol, Policy Press

Spencer, J. and Broad, R. (2012), 'The 'Groundhog Day' of the Human Trafficking for Sexual Exploitation Debate: New Directions in Criminological Understanding', European Journal on Criminal Policy and Research, 18: 269-81 
Spolander, G., Engelbrecht, L., Martin, L., Strydom, M., Pervova, I., Tani, P., Sicora, A., Adaikalam, F. (2014) The implications of neoliberalism for social work: Reflections from a six-county international research collaboration International Social Work 57(4), 301-312

Staerklé, C. (2013) Political lay thinking as representations of social order. In T. Magioglou T. (Ed.), Culture and Political Psychology: A Societal Perspective. Advances in Cultural Psychology: Vol. 7, Constructing Human Development (49-74). Charlotte, Information Age Publishing

Stark, C. (2017) The neoliberal ideology, its contradictions, the consequences and challenges for social work Ljetopis Socijalnog Rada 25(1), 39-63

UNODC (2018) Global Report on Trafficking in Persons Geneva https://www.unodc.org/documents/data-and-

analysis/glotip/2018/GLOTiP 2018 BOOK web small.pdf [Accessed 1 October 2019]

UNICEF (2015) Achieving a Durable Solution for Trafficked Children London, UNICEF UK

Van Dyke, R. (2017) Monitoring and evaluation of human trafficking partnerships in England and Wales Anti-Trafficking Review, 8, April, DOI: 10.14197/atr.20121788 http://www.antitraffickingreview.org/index.php/atrjournal/article/view/230/220

[Accessed 20 October 2019]

Wallace, MM., and Wylie, K. (2011) Child Trafficking: A Scottish Perspective Commonwealth Judicial Journal 19, 1, June

Wallace, J., and Pease, B. (2011) Neoliberalism and Australian social work: Accommodation or resistance Journal of Social Work 11(2), 132-142

Webb, SA. (2006) Social Work in a Risk Society Basingstoke, Palgrave Macmillan

Weitzer, R. (2013) Sex trafficking and the sex industry: The need for evidence based theory and legislation Journal of Criminal Law and Criminology 101(4), 1337-1370

Weitzer, R (2014) New Directions in Research on Human Trafficking THE ANNALS of the American Academy May 653, 6-24 May DOI: 10.1177/0002716214521562

West, A. (2017) Child trafficking and child welfare Journal of Human Trafficking 3(2), $125-135$

Westwood, J. (2016) Unearthing melodrama: moral panic theory and the enduring characteristic of child trafficking in Cree, V., Clapton, G., Smith, M. (eds) Revisiting Moral Panics Bristol, Policy Press 
Yea, S. (2017) 'Editorial: The politics of evidence, data and research in anti-trafficking work', Anti-Trafficking Review, issue 8, 2017, pp. 1-13, www.antitraffickingreview.org [Accessed 27 October 2019] 